\title{
New Foreword
}

ZHAO TINGYANG AND THE TIANXIA WORLD

Odd Arne Westad

Tianxia is a Chinese term that literally means "All under Heaven." In ancient Chinese philosophy and political theory it came to signify the realm of humans (as opposed to the possible realms of spirits, immortals, or gods). ${ }^{1}$ Very often it was used to signify the world as it was known to the Chinese and sometimes the territory that was ruled, or in theory should be ruled, by one of the Chinese states. In its origin, tianxia is a complex, composite, and contested term. Many Chinese thinkers have tried to simplify or universalize it. In the Analects, Confucius used tianxia to claim universal morals but also to argue for global human capacities: "To be able to practice five things everywhere under heaven constitutes perfect virtue[:].... Gravity, generosity of soul, sincerity, earnestness, and kindness." ${ }^{2}$

This book presents the views of Zhao Tingyang, a distinguished Chinese political philosopher who is now a professor at the Chinese Academy of Social Sciences. Zhao has for some time been preoccupied with finding ways in which Chinese thinking, and especially terms and practices that come out of Chinese antiquity, can be helpful in overcoming what he sees as today's decaying and unjust global order. Professor Zhao puts the concept of tianxia at the center of these efforts. "Tianxia," says Zhao, "is an 
ideal concerned with achieving cosmopolitical order." But although he is inspired by the Chinese past, Zhao is very careful in not presenting his version of "under heaven" as a direct transposition from what existed three thousand years ago. His tianxia is characterized by its utility for contemporary conditions, in which "we must go above and beyond the nation state as a horizon for understanding world politics. We need to take the world as a measure for defining political order and political legitimacy."3

Zhao's ideas are, very understandably, seen as significant within China and abroad. He has been lauded by many, both for taking on a number of challenges with regard to how to critique today's international system and for his knowledge of Chinese political theory from the pre- and early Confucian era and from later periods. First and foremost, Zhao has been praised for his attempts at applying some of these concepts toward a reconceptualization of our thinking about international relations today. In a world that is in desperate need for theory that is not originating from the same predominant Western sources, Zhao's work is both important and refreshing. Alongside a number of other Chinese political theorists of the global and international, such as Qin Yaqing and Yan Xuetong, Zhao has provided a body of work that set pathways for other scholars, inside and outside of China, to engage with and critique. ${ }^{4}$

A main strength of Zhao's work lies in his invitation to take the principle of one world as the starting point for global thinking. "In the political sense tianxia refers to a world political order," Zhao says. "A tianxia system has only internality and no externality. This also cancels out the semantic value of 'foreigner' and 'enemy' within political discourse." Correctly, he complains, "the current world is actually still functioning as a 'nonworld'; it is only a geographic category of existence and not a political one. The most important future political problem will be how to create a world, which would be to complete the process of world internalization."

Zhao insists that such a world order would have to be pluralistic. "Simply put," he argues, "what the tianxia system anticipates is a world order based on the principle of coexistence," in which "any political entity maintaining externality must become a problem of reconciliation and not an object to be conquered or colonized." It is hard not to welcome such a pluralistic and heterogeneous approach to what future world orders may consist of, especially given how often the West has misused its own values 
and its own patterns of law and institutions to gain control over others. Zhao's views on pluralism, theoretical as well as political, is one of the main aspects of his philosophical approach.

One must also welcome his willingness to take the past seriously, both as inspiration and to understand long-lasting practices. Zhao's views are (mainly) limited to the Chinese past, although this is understandable, both given his own background and the significance of China on a global scale (which Zhao, again understandably, presupposes without investigating much further). The weight of the past is perhaps more visible in Chinese discourses than in any other cultural and philosophical tradition I know, and Zhao is entirely correct in taking it as the starting point for his investigations, without feeling constrained by it. Zhao is an innovator as much as a continuator of the past, in the best tradition of Chinese thinking.

Zhao is particularly insistent that a major objective of any kind of thinking about international orders must focus on the need to avoid war. "To say that war is politics continued by other means (the viewpoint of Clausewitz) is not as good as saying that war is a failure of the political," Zhao contends. Any war is a setback, and war between "leading countries" (which Zhao uses instead of "great powers") will mean that the world itself is under threat. Any kind of system that prevents wars has a positive value in it, in Zhao's view. Part of the purpose of establishing a tianxia that states voluntarily participate in and which helps resolve common problems is to preserve the peace and over time remove war as an instrument of international relations.

A final strength of Zhao's political philosophy is his emphasis on the preservation of the global commons. Part of the argument for an expanding tianxia is that previous systems have led to unacceptable levels of environmental damage of what is not governed by individual states. The United Nations is not capable of rising to the occasion, and a new system is needed in which decisions can be made and implemented on a global scale. And such a system can only be put into action when all people, not just Westerners, feel that their interests and values are looked after within one world.

Other aspects of Zhao's views have led to criticism. His emphasis on the role of states over the role of nonstate groups and individuals is one 
of these. When Zhao speaks of compatibility, he often speaks of "compatibility of countries." When he, with reason, criticizes "the ideology of hegemonic nation-states where other nation-states and even the high seas are just territories to be dominated," it is injustice among states that preoccupies him. He echoes Mao Zedong's "three worlds" theory in saying that "the interests of the peoples of Europe and America and the interests of the people in the rest of the world are not coincident," but Zhao's reflections on this incompatibility is always kept at the state level. ${ }^{6}$ The problem with this is that it is hard to imagine how states, who (therefore) have their own narrow interests to look after, can move to the next level of cherishing the tianxia without being in some way forced to do so. There seems to be little in the idea of state sovereignty (which Zhao at least accepts and sometimes comes close to seeing as a positive) that will produce a tianxia.

There is, of course, the possibility that today's rising states outside Europe and North America will be different in their approach than the European-origin states have been. "What is most perplexing," Zhao asks somewhat rhetorically, "is why global justice remains such an unrealizable possibility?" He answers immediately: "The reason is not particularly mysterious or profound. It is just because hegemonic nation-states still hold a pronounced strategic advantage, and they use every possible way to preserve this advantage." All of which is true, although it slightly contradicts Zhao own emphasis on states, unless of course there are states that in their nature are different from the United States and its European predecessors.

Although he never states it plainly, it is Zhao's view that China is different from such hegemonic practices today and will remain different in the future. China is not and will not be imperialist; it will not be like the United States, which "carried out some institutional renovations within imperialism, turning modern imperialism into a globalizing imperialism.” China will help build a tianxia, because "the tianxia concept itself carries a very heavy affective dimension, and carries with it the entirety of Chinese history, its traditions, its experience, and its spirit." Zhao declares, "China is a 'world-pattern state' that takes tianxia to be internal to its structure."

Since, as Zhao correctly notes, we cannot say much for certain about the future, this is an argument that is based on a view of China's past and present. And it is here that the tianxia concept becomes most problem- 
atic. In Chinese antiquity "the Zhou dynasty tianxia system as an 'earth web' has an ancestral state at its center serving to oversee and protect the world," Zhao contends. This was a stable and beneficial system for a long time, and "the decline of the Zhou dynasty was very likely a result of being unable to live up to its own high standards of moral governance." The problem with all of this is of course that historically it is as, if not more, likely that the Zhou collapse came because others would no longer be ruled by the Zhou. There is no evidence that the Zhou state, or later Chinese states or empires, were as inclusive or harmonious as Zhao claims them to have been.

As some of Zhao's critics have noted, this becomes especially problematic when there is no attention to Chinese expansion, predomination, and hegemony in the past. Zhao's understanding of the Chinese past can sometimes seem a bit naïve, as when he asserts that "the distinction between 'civilized' [hua 华, also meaning Chinese] and 'barbarian' (yi 夷) was merely a way of referring to differences of natural geography, life styles, and cultural customs. As such, this was a 'descriptive' conceptual cluster without any racist or ethnocentric prejudice involved." This flies in the face of very durable traditions of Chinese exceptionalism and preoccupations with race, some of which Zhao must be aware of.

Zhao also seems to think that today's China has got its present geographical shape "as the central plain cultures continually expanded and radiated outward into the periphery," and worse, that "the 'Hanification' of China has an inherent connection with the spiritual attraction of Han culture." In reality, much of the expansion of China, as with all empires, happened through conquest and subordination. Ask today's indigenous populations in Tibet, Xinjiang, and Mongolia. When Zhao, quoting Wang Tongling, claims "that no matter who held political leadership in China, political power and the ruling class was always open to all ethnicities," then it is correct to note that there are examples of openness and examples of closedness in Chinese history. Today's ruling Politburo of the Chinese Communist Party has no member who is not Han Chinese.

Given the problems China is facing in terms of governance, some of Zhao's critique of democracy elsewhere rings a bit hollow. He is undoubtedly right that "many factors can mislead democracy into a distorted expression of the people's shared aspirations. For example, manipulation 
by wealthy interests, propaganda, speculation, passion, ignorance, fake news, and so on can all mislead popular opinion." But Zhao's main point is that Chinese traditions can lead the world toward a better future. And given the state of pluralism in China itself today, this does not seem like a safe bet. As long as political dissidents, trade union activists, and minority right advocates can be arrested and kept in prison simply for expressing their views, China will not seem a guarantor for "expansive harmony" in the world. Zhao is of course aware of this, and we can assume the reasons why he cannot openly critique it. But the sorry state of affairs of justice within China does present problems for his overall theory, too.

The biggest challenge for the tianxia concept in the future is, as in so many other cases, about who will call the shots. Zhao wants to see a more inclusive and just world, with effective governance of expanding global commons. It is hard not to agree with such a vision. But it is also hard to see who will lead us toward it. China has rich traditions of governance and political thought, and Zhao Tingyang does us all a favor in explaining them and setting out agendas for how they may be of use in the future. Just like China will learn from the rest of the world, the world will learn from China. Whatever we think of the tianxia concept, we know that there will be more Chinese involved in debates about global governance in the years to come. And, for most of them, the traditions that Zhao draws from will be central to their thinking. By reading his work, we will all be better prepared for joining in the multifaceted dialogues that are certain to come. 